\title{
Grammar policy and pedagogy from primary to secondary school
}

\author{
Ian Cushing, University College London
}

Accepted for publication in Literacy

\begin{abstract}
Grammar is a key focus of current UK national curriculum policy (DfE 2013a, 2013b), at both primary and secondary school level. But grammar policy across these levels is incongruous: at primary level, policy is largely prescriptive, framing language as a system of constraints and rules, whereas at secondary level, policy is much more geared towards descriptive, functional linguistics. Using data acquired from a survey with 275 secondary English teachers and interviews with 24 secondary English teachers, I critically explore how the incongruity of primary-secondary level grammar policy is impacting upon grammar pedagogy at secondary level. Using a combination of thematic and metaphor analysis, I show how many teachers report secondary students conceptualising grammar as a list of technical terms, with little idea or experience of how to use this knowledge in applications such as critical reading or creative writing. I also show how some secondary teachers were aiming to integrate grammar into their teaching, looking to build and develop on the grammatical knowledge students have from primary level. The data shows that teacher and student conceptualisations of grammar are shaped by curriculum policy, and I call for a more coherent and coordinated vision of grammar across primary and secondary level.
\end{abstract}

\section{Introduction}

The 2014 National Curriculum for English in the UK places a significant emphasis on grammar, at both primary (DfE 2013a) and secondary level (DfE 2013b). Compared against previous versions, the current curriculum (henceforth NC 2014) includes a radical increase in the amount of grammatical knowledge that students - and teachers - are expected to know about. Along with these changes, one of the more controversial moves by the UK government has been the introduction of the Grammar, Punctuation and Spelling (GPS) assessments. These are compulsory tests for primary school students in which they are tested on their knowledge of just under 40 grammatical terms (see Table 1, below). Throughout Key Stages (KS) 1-4 ${ }^{1}$, teachers are working with a detailed grammar glossary (DfE 2013c), a 19-page list of terms with definitions and examples. As the following sections will argue, there is a clear incongruence across primary-secondary grammar policy, with primary school grammar framed around prescriptive rules and linguistic 'correctness', and secondary school grammar geared much more towards descriptive linguistics. Given such radical changes to the grammatical content of the curriculum, especially at primary school, it is expected that grammar teaching at secondary school has been affected as a result, yet there is no existing research that looks at the exact nature of this. This paper presents research which attempts to do this, based on data acquired from a survey with 275 secondary English teachers and follow-up interviews with 24 teachers.

\section{Grammar, the curriculum and English teachers}

Grammar teaching in UK schools has a long history, shaped by a synergy of interrelated factors. Some of these include: (1) the amount and type of linguistics research in universities (Hudson \& Walmsley 2005); (2) successive government interventions such as the National Literacy Strategy and Language in the National Curriculum (see Hudson 2016 for a discussion on policy intervention on grammar teaching); (3) teachers' grammatical subject knowledge, which is typically limited (e.g. Borg 2003; Cajkler \& Hislam 2002), (4) a lack of grammatical content on many teacher training courses (see Giovanelli 2016a), and (5) teacher attitudes towards grammar, which are often framed in negative ways (e.g. Watson 2015). Different versions of these 'grammar histories' can be found,

\footnotetext{
${ }^{1}$ The National Curriculum in England and Wales is divided into Key Stages (KS), blocks of years from primary school (KS1-2, ages 5-11), secondary school (KS3-4, ages 11-16) and post-compulsory (KS5, ages 16+) study.
} 
amongst others, in Hudson (2016) and Hudson \& Walmsley (2005). Whilst the brief history given in this paper begins with the lead up to and implementation of NC 2014, it is important to note that grammar has always had a particularly difficult relationship with English teachers, with language work often deemed to be less important and valuable than literature. UK English teachers typically identify as 'literature specialists', with a prototypical (Rosch 1975) member of the ENGLISH TEACHER category entering the profession after completing a degree in English literature and wanting to share a love of reading - not grammar or linguistics - with young people (e.g. Goodwyn 2002). Many studies have suggested that English teachers generally consider 'literature' to be a core attribute of their professional identity (e.g. Ellis 2007; Goodwyn 2002), whereas 'language' can be construed as a threat (Watson 2015) and as a result, remain on the pedagogical periphery.

\section{National Curriculum 2014}

At the end of KS2, children in UK state education take compulsory grammar tests, introduced in 2013 by the Conservative government after the Bew Report (DfE 2011) recommended that technical parts of language such as grammar, spelling and punctuation could and should be tested, on the grounds that there are "clear "right" and "wrong" answers' (DfE 2011: 60). In these, students are tested on their ability to identify elements of grammatical form-function in decontextualised, synthesised example sentences. For example:

\section{Circle the adverb in the sentence below.}

Of all the toys in his large collection, Karl's little brother liked

the cuddly rabbit best.

\section{Figure 1: GPS test question}

Test questions follow a variety of formats and task types, such as choosing answers from multiple choices, inserting punctuation marks, and identifying grammatical concepts in sentences. All questions are based on synthetic sentences, rather than actual language use, written in standard English (SE). My criticism in this paper is not in the fact that children are learning about grammar, but how grammar is framed and presented in these tests and on the primary curriculum, with particular concerns around decontextualised language use (whereby invented examples are used to typically demonstrate a point about grammatical structure), identification of grammatical features without reference to meaning, and the primacy of SE (discussed further below).

The grammatical terms that primary students are expected to be familiar with are shown in Table 1, where I have organised them into grammatical form-function.

\begin{tabular}{|c|c|c|c|}
\hline \multicolumn{3}{|c|}{ Grammatical form } & \multirow{2}{*}{\begin{tabular}{l}
\multicolumn{1}{c}{ Grammatical function } \\
subject \\
object \\
adverbial
\end{tabular}} \\
\hline $\begin{array}{l}\text { Word classes } \\
\text { noun } \\
\text { pronoun } \\
\text { relative pronoun } \\
\text { possessive pronoun } \\
\text { determiner } \\
\text { verb } \\
\text { modal verb } \\
\text { auxiliary verb } \\
\text { subjunctive } \\
\text { perfect } \\
\text { progressive } \\
\text { adjective } \\
\text { adverb } \\
\text { preposition } \\
\text { conjunction } \\
\text { subordinating } \\
\text { coordinating }\end{array}$ & $\begin{array}{l}\text { Phrases } \\
\text { phrase } \\
\text { noun phrase } \\
\text { adjective phrase } \\
\text { preposition phrase } \\
\text { adverb phrase } \\
\text { Tense } \\
\text { simple present } \\
\text { simple past }\end{array}$ & $\begin{array}{l}\text { Clauses } \\
\text { clause } \\
\text { subordinate clause } \\
\text { relative clause } \\
\text { statement } \\
\text { question } \\
\text { exclamation } \\
\text { command } \\
\text { active } \\
\text { passive }\end{array}$ & \\
\hline
\end{tabular}

Table 1: Grammatical terms to be learnt by KS2 students in preparation for the GPS tests 
The GPS tests are seen as controversial for a number of reasons. For many students, high-stakes assessments can be a source of anxiety and stress (e.g. McDonald 2001), and many parents have reacted to this by boycotting the tests by keeping their children out of school (Adams 2016). Many teachers feel insecure about their own grammatical subject knowledge, unconvinced about the amount of metalanguage required, and are critical of the decontextualized grammar content (Bell 2015; 2016; Safford 2016). Some academics have - and continue to - criticise the curriculum content in failing to provide any meaningful pedagogic guidance on grammar teaching (e.g. Bell 2015, see also discussion below) and reducing grammar to the 'feature-spotting' or 'naming of the parts pedagogy', which had characterised what is often called 'traditional' grammar teaching in the early 1900s (Crystal 2013). Some public figures expressed concern about the validity of the grammatical content and the kind of reductive language knowledge which the tests can be seen to promote (e.g. Rosen 2015). Indeed, the United Kingdom Literacy Association issued a position statement which opposed the tests on the grounds that decontextualized grammar teaching does nothing for writing development (UKLA 2013).

Another concern is that discourse about grammar on the primary curriculum is largely prescriptive. This can be understood as a form of language planning, whereby a specific form and register of a language is promoted over others, revealing linguistic ideologies (Ferguson 2006; Barakos and Unger 2016). Prescriptivism and language planning in the GPS tests is manifested through notions of linguistic 'correctness': students must identify the 'correct' use of language namely SE - from a list of sentences whereby some options are 'incorrect'. For example, the use of a plural subject with the verb was (as in we was waiting in the playground) is deemed to be 'incorrect', even though for some varieties of English (such as non-standard London English), the use of this construction is perfectly acceptable usage and an important marker of linguistic identity (Cheshire and Fox 2009).

In addition to what might be thought of as a prescriptive discourse around grammar, the primary curriculum has little to say on the kind of grammar pedagogy that teachers might engage in, despite a body of research evidence pointing to the benefits of a contextualised grammar pedagogy (e.g. Cushing 2018; Myhill et al. 2012). Contextualised grammar is characterised by grammar being explored in relation to authentic texts, with a focus on how textual patterns and linguistic choices serve to create meaning, and why these might differ across genres. When grammar is taught in this way, it has been shown to improve writing ability (Myhill et al. 2012), critical reading ability and sensitivity to literary language (Cushing 2018; Giovanelli 2016b), and also enable teachers to conceptualise grammar in more positive ways (Watson 2015). This kind of pedagogy, which draws on Halliday's systemic functional grammar (e.g. Halliday and Matthiessen 2004) - has long been called for as a grammar appropriate for schools (e.g. Clark 2010: 192) and has had significant impact in various Anglophone countries (see various chapters in Locke 2010, see Macken-Horarik et al. 2011 for an Australian perspective, and see Kolln \& Hancock 2005 for a rhetorical-grammar, US-based perspective).

Grammatical 'guidance' on the primary curriculum is presented as a seemingly arbitrary set of specific grammatical constructions that students should be able to use by a certain age, such as 'using fronted adverbials' in years 3 and 4, and 'using expanded noun phrases' by year 2 (DfE 2011b). Safford (2016) showed that for many teachers, the test design is leading grammar pedagogy, with the 'language and format of the test strongly influencing the way grammar is taught (2016:11), i.e. decontextualised grammar teaching with students using grammatical terms with little meaningful applications in text analysis or their own writing. Given that grammatical competence not only refers to 'grammatical subject knowledge' but also a capacity to notice how grammar makes meaning in texts (Myhill et al. 2013), it would seem that the primary grammar curriculum is skewed in favour of the former.

At secondary school, curriculum language policy has typically been much more geared towards descriptive, functional, and contextualised grammar. The $2014 \mathrm{KS} 3 / 4$ curriculum stipulates that - amongst other things - students are expected to engage in the analysis of how grammatical choices serve to construct meaning. The following is taken from the secondary curriculum (DfE 2013b), where I have italicised phrases deemed to be promoting descriptive and functional grammar: 
Pupils should be taught to. [...] read critically through:

- knowing how language, including figurative language, vocabulary choice, grammar, text structure and organisational features, presents meaning

and

- studying the effectiveness and impact of the grammatical features of the texts they read

- drawing on new vocabulary and grammatical constructions from their reading and listening, and using these consciously in their writing and speech to achieve particular effects

- knowing and understanding the differences between spoken and written language, including differences associated with formal and informal registers, and between Standard English and other varieties of English

- discussing reading, writing and spoken language with precise and confident use of linguistic and literary terminology.

(DfE 2013b: 4-6)

The foregrounding of this kind of grammar, where clear links between textual patterns, meaning and readers' responses are made, are at a clear incongruence with the kind of grammatical discourse in the KS1/2 curriculum. Whilst KS4 students are still assessed on their use of metalanguage in high-stakes assessments, this is done so in context: the idea being that students analyse literary and non-literary texts, using what they know about linguistic concepts to help them interpret meanings, authorial choices and writers' motivations.

An additional level of incongruence lies in the fact that there may well be a difference between curriculum policy and pedagogical practice, as has been identified in relation to previous versions of the curriculum. For example, Lefstein (2009) compared the 'rhetorical' view of grammar in the National Literacy Strategy (e.g. DfEE 2000) policy documentation against the largely prescriptive grammar teaching enacted in one primary school (see also Phipps and Borg (2009) and Watson (2015) for other discussions of incongruence between policy, teacher beliefs and classroom practice).

With this context in mind, I present my method for better understanding how curriculum policy has impacted on grammar teaching in secondary schools, and what teachers' perceptions of these changes are.

\section{Method}

The aims of this research were to better understand how NC 2014 policy has impacted on grammar teaching in secondary schools, and what teachers' perceptions of these changes are. To do this, I designed and administered an online survey and a series of interviews with UK secondary school English teachers. This was part of a wider project looking at KS3 grammar pedagogical practice (e.g. Cushing, in press; Cushing 2018). This research thus adopts a discursive approach to critical language policy, whereby the analysis of policy documents (in this case education policy) is incorporated with the views and experiences of policy arbiters (in this case teachers).

An online survey was designed and administered, in order to acquire a snapshot of English teachers' views. The survey included 21 questions, broken into sections: Section 1 asked for participant information; Section 2 asked participants to evaluate a list of statements using five-point Likert scales, about self-identified confidence in the grammatical content of the National Curriculum, and Section 3 asked participants to reflect on classroom practice in the teaching of grammar, including if and how NC 2014 had affected this, and what their perceptions of these changes were. In the discussion that follows I focus on results from Section 3, given I am interested in teachers' perceptions on policy change. Calls for participation were placed online, through email lists such as The English Language List (an active email discussion list for UK English teachers), the Times Educational Supplement online forum, and social media channels. Although only secondary English teachers were invited, I had no control over who actually responded. The sampling procedure for the 
survey was restricted to teachers who are active online and who use the platforms where it was advertised. 275 participants completed the survey.

In order to build on the survey data, I conducted semi-structured interviews with 24 English teachers, who were all working in UK secondary schools. These participants were identified through the survey, who in the final survey question had expressed willingness to take part in interviews. Interviews lasted between 15-45 minutes and were audio recorded and then transcribed, which generated a corpus of 79,840 words. Questions were geared around teachers' experience and conceptualisations of grammar teaching, especially in light of the changes to NC 2014.

Using NVivo software, survey and interview data were inductively coded at a micro-level.

Discourse was only coded if it related to the specific research focus, namely around how grammar and grammar pedagogy was conceptualised in relation to current policy. As such, the codes that are of interest to this paper are: curriculum grammar policy, grammar teaching, metalanguage, attitudes to grammar and knowledge about language. These codes were used as themes to organise the first three data analysis sections.

All data was also tagged for metaphor, using the Metaphor Identification Procedure as developed by the Pragglejaz Group (2007). Metaphors reveal ways of thinking and knowing, about certain assumptions and beliefs that are held by individuals and groups (Semino 2008), and for understanding how people construct the world, in a range of real-world settings such as classrooms (e.g. Cameron 2003). My analysis makes use of the conventions established in Lakoff and Johnson (1980) by presenting metaphors in a X IS Y structure. Here, X is the 'target domain' (the thing being described) and $\mathrm{Y}$ is the 'source domain' (the thing that information is exported from). For example, the expressions such as 'grammar is the foundation of communication' and 'grammar is about sentence construction' can both be captured or 'packaged' by the metaphor of GRAMMAR IS A PHYSICAL STRUCTURE, where GRAMMAR is the target domain and PHYSICAL STRUCTURE is the source domain. The final analysis section focuses on the use of metaphor in the datasets, looking particularly at the target domain of GRAMMAR and the various source domains it was mapped with.

\section{Analysis and discussion}

The following sections report on data from the survey and interviews. The first section presents an overall picture of the impact of KS2 changes, before looking at more specific issues related to grammatical metalanguage and grammar pedagogy. Responses are tagged using the following conventions: [s/iXXX], where [s] stands for survey response and [i] for interview response, and XXX for participant number.

\section{The impact of KS2 changes}

Results revealed that teachers perceive the KS2 curriculum as having a significant impact on grammar teaching at secondary school. This was mostly established via responses to Q20 of the survey, which asked:

\section{Has the renewed emphasis on grammar on the English curriculum at KS2 had an impact on your teaching practice? If so, how?}

Whilst some participants reported that even before NC 2014 they had 'always incorporated grammar into their teaching' [s015] and that 'you can't teach English without teaching grammar in tandem' [s152], the majority of responses reported that changes to grammar in NC 2014 had actively changed their teaching. These changes were felt in terms of teachers feeling the need to increase their focus on grammar, teachers' and students' knowledge of grammar, and an increase in the use of metalanguage in classroom discourse. These findings are in line with what Safford (2016) found for a primary school context. Some responses to these changes were framed in negative ways, with grammar being seen as something that takes away time from other 'more important' aspects of the curriculum, such as reading for pleasure and creative writing:

Have had to re-write all my schemes of work [...] reduces time frame for study of other important aspects of English like writing [s016] 
We do more grammar than ever before at KS3 because of what's happened to KS2 and KS4. It takes up time that could be done doing more valuable things like fostering a love of reading [s051]

Of course, all teachers will hold different opinions about what constitutes the 'least or most important' aspect of their profession. As discussed earlier, the fact that most English teachers profess a deep love of literature - which can manifest itself at the expense of language work in the classroom - is welldocumented, e.g. Goodwyn (2002). Comments such as the ones above appear to suggest that grammar is shifting from a previously peripheral aspect of the curriculum towards a more core or central aspect. The vast majority of the interviews confirmed the fact that changes to KS2 policy had impacted on KS3. For example (dots in brackets indicate a short pause; underline indicates emphasis):

I would say that we have certainly upped our focus on the teaching of grammar (.) particularly at key stage three as a result of the changes to key stage two particularly the grammar test that is now undertaken [i22]

it's definitely (.) absolutely different (1) because I've kind of been teaching the year sevens before coming up from primary school and then the same year sevens coming up like you know after this new after the new kind of format the way that they're looking at it and it's just completely different [i08]

yeah massively it's a total total shift from what we've normally had at key stage three [i15]

Responses such as these undoubtedly demonstrate that current KS3 grammar teaching has changed as a result of primary curriculum changes in NC 2014. Many participants reported how changes to the curriculum had prompted them to update their grammatical knowledge, especially for those teachers who had received little or no training in grammar. As acknowledged earlier in this paper, teacher knowledge and confidence in grammar is typically low, so it is expected that teachers have had to do this. What is perhaps worthier of comment is that fact that many teachers receive very little support in doing this, and have had to effectively train themselves:

I had to do some serious independent CPD being a child of the eighties who wasn't taught this stuff explicitly [s04]

I've certainly had to swot up on grammar myself [s133]

The government's failure to provide resources and time for updating teachers' grammatical and pedagogical knowledge is an ongoing issue, with many teachers feeling 'stranded' [s068] in where to look for training and professional development.

A number of responses also talked about the difference between KS3 and KS4 students' grammatical knowledge, especially in making sure that KS2 grammar was maintained and developed:

I now teach grammar once a fortnight to each of my KS3 classes; this works well with my Year 7 class who are familiar with the new SATs ${ }^{2}$ and focus on grammar, however, my KS4 classes generally struggle with the terminology and application of grammar points as this was not taught thoroughly at primary school. [s134]

I have argued elsewhere (Cushing 2018) that current KS3 presents an ideal time for teachers to build on what students know about language, especially in making grammatical work more applied and contextualised. The following section discusses teachers' approaches in doing this in further detail.

\section{Metalanguage}

\footnotetext{
${ }^{2}$ Statutory Assessments taken in UK primary schools, of which the GPS test is one of.
} 
Negative discourse about grammar was especially geared towards metalanguage. This is perhaps to be expected, given that one of the major changes to the KS2 curriculum was an increase in the need for students to learn about metalinguistic terms. The grammatical glossary (DfE 2013c) foregrounds the importance of metalanguage, and knowledge of this is often the source of teachers' anxiety about grammar. However, whilst students' use of metalanguage in classroom discourse and written work was perceived to have increased, many participants reported that this was often done at the expense of other things - namely discussions of linguistic meaning and responses to literary texts:

Use of terminology has increased but I don't think it has resulted in students making more meaningful comments [s023]

The KS2 changes have had a real impact because kids come up with all this random terminology but with absolutely no ability to say why such a word is being used or what the connotations of that word might be [i15]

If you say to them if you mention some terminology or what's the writer's method they will quite nicely put this word is a verb but they're not very good at the kind of subtle handling of terminology it is a kind of tick box exercise and yeah feature spotting [i20]

The association of metalanguage with 'feature spotting' was prevalent across the data, with participants using verbs such as 'hunt', 'identify' 'spot' and 'look for' to describe the ways in which students identified grammatical features, but often failed to apply this into analysis or writing. Again, this is perhaps to be expected - the GPS tests assess decontextualised grammatical knowledge, with no real requirement for students to discuss how grammatical constructions and choices convey meaning in texts. For example, i21 talked about how even though beginning KS3 students had knowledge of metalinguistic concepts, they were unable to apply this knowledge in terms of analytical reading or creative writing (where $I n t=$ interviewer):

Int: $\quad$ so they have the vocabulary so they can recognise the terms and they are familiar with the terms is that right?

i21: they know the terms they can identify things but they often can't talk about what they are doing or the effect of them

i01 suggested that feature-spotting was a result of KS3 students' applying the KS2 assessment criteria into their work:

they just spot things and point them out and think that's what you want because that's what they were rewarded for before and so you want them to understand why that's there or why that's been used or what's happening [i01]

As argued earlier, the KS2 and KS3 curriculum are somewhat incongruous in the way that grammar is presented. Whilst at KS2, the nature of the GPS tests emphasises grammatical work as reductive feature-spotting, KS3 and KS4 requires students to apply grammatical knowledge in terms of discussing meaning, emphasizing the need for a contextualised grammar pedagogy. I suggest that KS2 grammar teaching and curriculum policy ought to be more in line with this kind of grammar. i15, who had previously suggested that changes to KS2 grammar had had affected her teaching 'massively', pointed out the challenges in knowing what to do with students' grammatical knowledge in terms of meaningful language analyses:

yeah and the challenge really feels now is how do we use that knowledge that they've got but then also how do we build on it? and how do we get the balance right between getting them to read for meaning and being able to analyse language? [i15] 
The challenges that i15 faced are a good departure point for this section, as the following section examines some of the ways that participants were trying to promote grammar as a system of meaning, rather than a set of decontextualised rules and terms.

\section{Integrating grammar}

The previous section showed how many KS3 teachers reported the tendency of students to featurespot and not apply grammatical knowledge to reading and writing, seemingly as a result of decontextualized KS2 grammar policy 'bleaching' into KS3.

In this section, I show how some participants were taking what students knew about grammar and using it in meaningful and enabling ways, leading to heightened sensitivity to literary language, as well as a more rounded knowledge about language. For example, i02 talked about how she was using grammatical knowledge to harness more nuanced understandings of writers' choices in literary discourse:

\section{I think once they have an effective understanding of grammar they can analyse literature much better because they think oh you know the role of this in a sentence the reason why we use this determiner and not this one (.) they can actually think about language and what it's doing much more effectively [i02]}

i02 reported feeling 'confident' about her grammatical knowledge and pedagogical principles, having sought out additional in-service training in contextualised grammar teaching. This confidence and training had helped her to move towards a meaningful grammar pedagogy, away from the kind of feature-spotting activities, which she deemed to have little material value:

because we weren't actually doing anything with that knowledge we were just teaching the kids to know how is that an adjective or an adverb and they weren't they weren't doing anything with it so the students couldn't see where it was going so they were turned off but it felt like something was kind of bolted on to the curriculum [i02]

Whilst I suggest that that a contextualised grammar pedagogy is indeed of value, teachers need access to training in how to successfully implement this in the classroom. I have made this argument in previous work (Cushing, in press), where I outlined a training course for teachers about contextualised grammar pedagogy, and how teachers collaborating with academic linguists had led to changes in the way that grammar was taught.

\section{Metaphor}

This section focuses on the use of metaphor for particular concepts, across the datasets. Metaphors provide an important way of understanding how concepts are construed ideologically, given that the source domain provides a lens through which the target domain is described.

Participants tended to construe the target domain of GRAMMAR metaphorically, using a variety of different source domains such as RULEBOOK, VIRUS and CONSTRUCTION MATERIAL. I focus on these source domains here given their high frequency in the data, and the way that they were used in reference to discourse about curriculum policy. Metaphorical construals for GRAMMAR were often negative. The RULEBOOK metaphor, which was the most frequently used source domain mapped with GRAMMAR across the dataset (e.g. grammar is the rules that dictates what we can and can't do with language [i02]), frames grammar as a system of strict regulations with forms that are deemed to be 'correct' or 'incorrect'. The same construal of GRAMMAR is found throughout the Bew Report (DfE 2011), in which the recommendation that grammar ought to be tested in a 'right/wrong' capacity was first made. Socio-functional linguistics would take serious issue with such a construal, given that for them, language is considered to be a meaning-making resource from which speakers make contextually grounded choices, steered by a cline of appropriateness (e.g. Halliday \& Matthiessen 2004; Myhill 2018).

Some participants held particularly vitriolic feelings about the emphasis on grammar in curriculum policy. In the following responses, participants employ a metaphor of GRAMMAR IS A 
VIRUS, suggesting how the emphasis on grammar has consequently 'infected' contemporary English teaching:

Grammar is like a virus that has spread from KS2 to KS3 and 4 [s019]

It's infected English. It's like the subject is diseased with grammar all of a sudden [s056]

It's painful. English teaching needs curing of grammar [s211]

The VIRUS metaphor reflects deep hostility towards grammar, construing it as not only something dangerous, unwanted and threatening, but also something to be purged, resisted and removed, to 'cure' English teaching of an 'illness'. We might take such discourse about grammar to be perfectly understandable, given the controversial nature of the GPS assessments, the ways in which they were installed under the then Education Secretary Michael Gove's 'testing regime' (Marshall 2017: 8), and the fact that changes to grammar came alongside other major changes to the English curriculum, such as new GCSEs and A-levels. But an oppositional discourse about grammar was also present in the data - one where it is seen not as a virus or rulebook, but as a 'tool for unpicking meaning' [s148], drawing on a CONSTRUCTION MATERIAL metaphor. However, as work has shown (e.g. Giovanelli 2015; Watson 2015), shifting conceptualisations of grammar towards more positive ones requires teachers to be trained in grammar; to see how it can operate as a meaning-making system and be used to improve analytical reading and writing.

In a discussion of how different metaphors radically affected an approach to grammar teaching, i24 spoke about how she had used the metaphor of GRAMMAR IS A CONSTRUCTION MATERIAL to think about grammar, as a resource that could be used to encourage creativity in the classroom:

designing and building (.) that's my aspiration of how to think about it (.) I think that's a really lovely way about crafting and designing (.) I really love the way that grammar is described there [...] you know grammar allows creativity in a sense [...] construction suggests it encourages creativity [i24]

Whilst i24's CONSTRUCTION metaphor framed grammar in useful ways and was obviously a powerful and enabling way for her to construe grammar, she still felt unable to implement contextualised grammar into her teaching. i24 identified as a 'literature specialist' and had received no formal training in linguistics, and talked about how she yearned to teach grammar in context, and knew that she 'should be doing that more', but felt she lacked the time and pedagogical knowledge to do so:

Int: $\quad$ you said earlier that your ambition was to be able to teach grammar embedded and integrated

i24: $\quad$ yeah I would love to (.) I should be integrating it more

Int: so why don't you if that's what you want to do? what do you think it is that stops you from doing that?

124: I I guess I'm looking at what other members of department are doing (.) there probably aren't many existing resources so we'll probably have to start from scratch [...] I've never really seen how that kind of grammar teaching can be done well

The use of spatial language in the exchange above (e.g. embedded, integrated) draws on a metaphor of ENGLISH STUDIES IS A SERIES OF SEPARATE PARTS, of which grammar is one. This metaphor was also used by i02 (discussed in the previous section), where grammar was construed as something that was 'kind of bolted on to the curriculum', framing the extent to which grammar is 'connected' or 'disconnected' to other aspects of the discipline. A 'bolted on' grammar pedagogy positions grammar as something rather secondary, attached to English teaching as a kind of gestural symbol rather than anything particularly meaningful. i14 also talked about how the benefits of a contextualised approach with enthusiasm, especially when 'pitted against' a decontextualised grammar pedagogy, suggesting 
that the SEPARATE PARTS view of English could lead to a reductive and inefficient grammar pedagogy:
I think I think yeah a contextualised approach absolutely (.) to be honest I think the other approach just kind of floating in a bubble I think is a complete waste of time (.) I think if you don't contextualise it you might as well not do it in the first place [i14]

Despite participants talking enthusiastically about a contextualised grammar pedagogy, some expressed reservations about over-emphasizing grammar when analysing texts, and despite best pedagogical intentions, how this could inadvertently lead to a de-focus on meaning:

I just (.) I just you know I think it's good to analyse texts to look at the language to see about the genre the identity (.) um you know different ways that personas are created and places but I think if you start just looking (.) completely dissecting a literary text then I think (.) Ijust think (.) I think it destroys the meaning (.) I think if you analyse it too much in that way I feel you start losing the meaning [i09]

The use of the ANALYSING TEXTS IS SURGERY metaphor, as in completely dissecting a literary text entails students picking apart language in sterile ways, performing operations on texts where the focus and aim is on extracting minute linguistic detail, rather than looking at whole-text meaning. Of course, such precise linguistic detail can be of benefit in the classroom, but there is a fine balance between picking apart - or dissecting - a text for the sake of it, and using what students know about grammar to systematically interpret how a text projects meaning.

\section{Implications and conclusions}

Using a critical discursive approach to curriculum policy, this paper has analysed secondary school teacher discourse about grammar in reference to changes to the grammatical content of NC 2014. Whilst previous studies have investigated grammar teaching at either primary or secondary level, very little is known about the transition between the two, especially in light of recent policy change.

I showed that many teachers report beginning KS3 students seeing grammar as a list of technical terms, with little idea or experience of how to make use of these terms and knowledge in applications such as critical reading or creative writing. Such a limited conceptualisation of grammar is, I argue, one of the results of the GPS test design, where KS1/2 students are led to conceptualise grammar as being technically 'accurate' and as a list of rules which have 'right' or 'wrong' answers, both of which are underpinned by a prescriptive grammar discourse and the metaphor of GRAMMAR IS A RULEBOOK. Perhaps more concerning is the fact that prescriptive grammar says very little about real-life language use, reflecting what 'should' be done with language rather than what actually happens. This view of grammar is in sharp contrast with a more socio-functional or cognitive approach to grammar, which construes grammar as a resource for shaping meaning (e.g. Halliday \& Matthiessen 2004). Research has consistently demonstrated that socio-functional/cognitive theories of grammar offer meaningful pedagogies (e.g. Cushing 2018; Giovanelli 2016b; Myhill \& Watson 2014) and although the majority of this work has taken place in a secondary school setting, I see no reason why these grammar pedagogies would not be suitable for primary level, if teachers had access to adequate training.

One of the reasons for descriptive linguistics being more prevalent in secondary schools is that current curriculum policy is much more geared towards this view of language (DfE 2013b). The data analysed in this paper showed how teachers valued a descriptive, contextualised and functional approach to grammar teaching, seeing grammar not as something 'separate' to the rest of the English curriculum, but as something that was 'embedded into' it, especially into the study of literary texts. The use of this language draws on the SEPARATE PARTS metaphor, and I suggest that metaphor analysis is a useful way of critically evaluating grammar curriculum policy and teacher metalinguistic discourse, in unpacking ideologies, beliefs and world-views. In many cases, the 'separation' or 'divide' of English into language and literature is reinforced at universities, although there is a growing movement calling for a more fully 'integrated' version of English, both in universities and schools (e.g. Clark and Macrae 2014). 
The aims of this research were to better understand how NC 2014 policy has impacted on grammar teaching in secondary schools, and what teachers' perceptions of these changes are. Although the research took place in the UK, I would like to suggest that the findings remain relevant to an international audience, especially given the amount of attention that grammar receives as a policy initiative and a research focus throughout the world (see Locke 2010). There are four main findings, summarised below:

- Grammar teaching has increased as a result of curriculum policy change, with many teachers feeling uncomfortable about the amount of grammar on the curriculum, especially in how it is construed as being a 'threat' to other aspects of the English curriculum.

- Many teachers report beginning KS3 students seeing grammar as a list of technical terms, with little idea or experience of how to use these terms and knowledge in applications such as critical reading or creative writing.

- Teacher tend to construe grammar metaphorically, and the types of source domains that this is mapped with (e.g. RULEBOOK; CONSTRUCTION MATERIAL) appear to have an impact on pedagogical practice. Further research is required to validate this, especially looking at how metaphorical construals in reported discourse about grammar correlate to pedagogy.

- Many teachers are contextualising grammar into their teaching, framing grammar as a resource for shaping meaning and building on KS2 grammatical knowledge.

Whilst I see this final finding a positive step forward, I would like to end this article by repeating Myhill and Watson's call for a more 'coherent theorization of a role for grammar in the curriculum' (2014: 54) and argue for a more nuanced vision of pre/in-service teacher education with regards to grammar and grammar pedagogy, as well as a more consistent vision of grammar across UK education policy.

\section{References}

ADAMS, R. (2016) Parents to keep children out of school in key stage exam boycott. The Guardian. Accessed $22^{\text {nd }}$ April 2018. Available at

$<$ https://www.theguardian.com/education/2016/may/01/parents-to-keep-children-out-of-school-inkey-stage-exam-boycott>

BARAKOS, E. \& UNGER, J.W. (2016) Discursive Approaches to Language Policy. London: Palgrave.

BELL, H. (2015) The Dead Butler revisited: grammatical accuracy and clarity in the English Primary Curriculum 2013-2014. Language and Education, 29.2, pp. 140-152.

BELL, H. (2016) Teacher knowledge and beliefs about grammar: a case study of an English primary school. English in Education, 50.1, pp. 14-21.

BORG, S. (2003) Teacher cognition in grammar teaching: a literature review. Language Awareness, 12.2, pp. 96-108.

CAMERON, L. (2003) Metaphor in Educational Discourse. London: Continuum.

CAJKLER, W. \& HISLAM, J. (2002) Trainee teachers' grammatical knowledge: the tension between public expectations and individual competence. Language Awareness 11.3, 161-177.

CHESHIRE, J. \& FOX, S. (2009) Was/were variation: A perspective from London. Language

Variation and Change, 21, pp. 1-38. 
CLARK, U. (2010) Grammar in the curriculum for English: What next? Changing English, 17.2, pp. 189-200.

CLARK, B. \& MACRAE, A (2014) Lang-Lit from A to BA: Integrating Language and Literature study at school and university. Higher Education Academy. Available at $<$ www.heacademy.ac.uk/knowledge-hub/langlit-ba-integrating-language-and-literature-study-schooland-university-0> Last accessed $10^{\text {th }}$ June 2018.

CRYSTAL, D. (2013) On a testing time. Available at: <http://davidcrystal.blogspot.co.uk/2013/05/on-testing-time.html> Last accessed $9^{\text {th }}$ March 2018.

CUSHING, I. (2018). 'Suddenly, I am part of the poem': texts as worlds, reader- response and grammar in teaching poetry. English in Education 52(1): 7-19.

CUSHING, I. (in press). Stylistics goes to school. Language and Literature.

DFE. (2011) Independent Review of Key Stage 2 Testing, Assessment and Accountability (The Bew Report). London: DfE.

DFE. (2013a) English Programmes of Study: Key Stages 1 and 2. London: DfE.

DFE. (2013b) English Programmes of Study: Key Stage 3. London: DfE.

DFE. (2013c) Glossary for the Programmes for Study for English. London: DfE.

DFEE. (2000) Grammar for Writing. London: DfEE.

ELLIS, V. (2007) Subject Knowledge and Teacher Education: The Development of Beginning Teachers' Thinking. London: Continuum.

FERGUSON, G. (2006) Language Planning and Education. Edinburgh: Edinburgh University Press.

GIOVANELLI, M. (2015) Becoming an English language teacher: linguistic knowledge, anxieties and the shifting sense of identity. Language and Education, 29.5, pp. 416-429.

GIOVANELLI M. (2016a) 'Developing beginning teachers' linguistic awareness: Issues and practice in ITE.' in M. Giovanelli \& D. Clayton (Eds.), Knowing about Language: Linguistics and the Secondary English Classroom. London: Routledge, pp. 186-197.

GIOVANELLI, M. (2016b) Readers building fictional worlds: Visual representations, poetry, and cognition. Literacy, 51.1, pp. $26-35$.

GOODWYN, A. (2002) Breaking up is hard to do: English teachers and that LOVE of reading. English Teaching, Practice and Critique, 1.1, pp. $66-78$.

HALLIDAY, M. \& MATTHIESSEN, C. (2004) Halliday's Introduction to Functional Grammar. London: Arnold.

HUDSON, R. \& WALMSLEY, J. (2005) The English Patient: English grammar and teaching in the twentieth century. Journal of Linguistics, 43.3, pp. 593-622.

HUDSON, R. (2016) The impact of policy on language teaching in UK schools. in M. Giovanelli \& D. Clayton (Eds.), Knowing about Language: Linguistics and the Secondary English Classroom. London: Routledge, pp. 25-35. 
KOLLN, M. \& HANCOCK, C. (2005) The story of English grammar in United States schools. English Teaching: Practice \& Critique, 4.3, pp. 11-31

LAKOFF, G. \& JOHNSON, M. (1980) Metaphors We Live By. Chicago: University of Chicago Press.

LEFSTEIN, A. (2009) Rhetorical grammar and the grammar of schooling: teaching powerful verbs in the English National Literacy Strategy. Linguistics and Education, 20.4, pp. 378-400.

LOCKE, T. (2010) (ed.) Beyond the Grammar Wars: A Resource for Teachers and Students on Developing Language Knowledge in the English/Literacy Classroom. London: Routledge.

MACKEN-HORARIK, M., LOVE, K. \& UNSWORTH, L. (2011) A grammatics 'good enough' for school English in the 21st century: Four challenges in realising the potential. Australian Journal of Language and Literacy, 34.1, pp. 9-23.

MARSHALL, B. (2017) The politics of testing. English in Education, 51.1, pp. 27-43.

MCDONALD, A. (2001) The prevalence and effects of test anxiety in school children. Educational Psychology, 21, pp. 89-101.

MYHILL, D. (2018) Grammar as a meaning-making resource for language development. L1Educational Studies in Language and Literature, 18, pp. 1-21.

MYHILL, D. \& WATSON, A. (2014) The role of grammar in the writing curriculum: A review of the literature. Child Language Teaching and Therapy, 30.1, pp. 41-62.

MYHILL, D., JONES, S \& WATSON, A. (2013) Grammar matters: how teachers' grammatical subject knowledge impacts on the teaching of writing. Teaching and Teacher Education, 36, pp. $77-91$.

MYHILL, D., JONES, S., LINES, H \& WATSON, A. (2012) Re-thinking grammar: the impact of embedded grammar teaching on students' writing and students' metalinguistic understanding. Research Papers in Education, 27.2, pp. 139-166.

PHIPPS, S. \& BORG, S. (2009) Exploring tensions between teachers' grammar teaching beliefs and practices. System, 37, pp. 380-390.

PRAGGLEJAZ GROUP. (2007) MIP: A method for identifying metaphorically used words in discourse. Metaphor and Symbol, 22.1, pp. 1-39.

ROSCH, E. (1975) Cognitive representations of semantic categories. Journal of Experimental Psychology: General, 104, pp. 192-233.

ROSEN, M. (2015) Dear Ms Morgan: in grammar there isn't always one right answer. The Guardian. Accessed 22 May 2018. Available at < https:/www.theguardian.com/education/2015/nov/03/morgangrammar-test-right-answer-spag-english-spelling-punctuation-grammar>

SAFFORD, K. (2016) Teaching grammar and testing grammar in the English primary school: the impact on teachers and their teaching of the grammar element of the statutory test in spelling, punctuation and grammar (SPaG), Changing English, 23.1, pp. 3-21.

SEMINO, E. (2008) Metaphor in Discourse. Cambridge: Cambridge University Press. 
UKLA. (2013) UKLA statement on teaching grammar. UKLA. Accessed 11 June 2018. Available at $<$ https://ukla.org/downloads/UKLA_statement_on_teaching_grammar_rev.pdf $>$

WATSON, A. (2015) Conceptualisations of 'grammar teaching': L1 English teachers' beliefs about teaching grammar for writing. Language Awareness, 24.1, pp. 1-14. 